\title{
NUTRITIONAL VALUE OF GRANULATED ADULT DOG FEED
}

\section{WARTOŚĆ ODŻYWCZA KARM GRANULOWANYCH DLA PSÓW DOROSŁYCH}

\author{
Department of Pig Breeding, Animal Nutrition and Food, West Pomeranian University of Technology, \\ Szczecin, Poland \\ ${ }^{1}$ Laboratory of Biology and Ecology of Parasites, West Pomeranian University of Technology, \\ Szczecin, Poland
}

\begin{abstract}
Streszczenie. Jedną $\mathrm{z}$ najpopularniejszych metod żywienia psów jest podawanie im pełnoporcjowych karm komercyjnych. Decydując się na karmienie psa suchą karmą, w jej wyborze należy kierować się nie ceną, ale przede wszystkim jakością. Materiał badawczy stanowiło 9 komercyjnych karm w formie granulatu przeznaczonych dla psów dorosłych. W suchej masie materiału badawczego oznaczono podstawowy skład chemiczny (białko ogólne włókno surowe, tłuszcz surowy, popiół surowy i bezazotowe związki wyciągowe). Dokonano również porównania wyników badań własnych z danymi, jakie podawali producenci na etykietach badanych karm. Na podstawie oznaczonego składu chemicznego wyliczono wartość energii metabolicznej każdej karmy. Wszystkie badane karmy spełniały przyjęte normy minimalnego zapotrzebowania na białko ogółem oraz tłuszcz surowy. Trzy spośród 9 karm nie zawierały zalecanego minimum energii metabolicznej. Porównując dane podawane przez producentów, dotyczące wartości pokarmowej karm, z wynikami analiz własnych, stwierdzono, że w kilku przypadkach producenci zawyżali bądź zaniżali zawartość poszczególnych składników pokarmowych. W sześciu spośród 9 badanych karm producenci podawali istotnie większą zawartość białka. W jednym przypadku producent podał istotnie mniejszą zawartość tłuszczu od wykazanej w przeprowadzonych analizach chemicznych.
\end{abstract}

Key words: dog feed, chemical composition, metabolisable energy.

Słowa kluczowe: karmy dla psów, skład chemiczny, energia metaboliczna.

\section{INTRODUCTION}

Nutrition is one of the most influential environmental factors for a dog (Mielczarek and Szydłowski 2017). It has direct effects on the animal's development, physical and mental condition, reproductive capacity and overall health of the body (Barteczko 2002; Witkowska 2015). There are many ways to feed a dog. It is the owner of the dog who decides on the best way to feed his pet, whether on the basis of food prepared on his own or ready-to-eat dry and wet feeds. (Ceregrzyn and Głowacka 2014; Mirowski 2014). Availability of a wide range of ready-to-eat complete feeds facilitates selecting the right feed for each dog, depending on its age, physiological condition, level of physical activity or potential health issues. One of the

Corresponding author - Adres do korespondencji: Wioletta Biel, Department of Pig Breeding, Animal Nutrition and Food, West Pomeranian University of Technology, Szczecin, Doktora Judyma 10, 71-460 Szczecin, Poland, e-mail: Wioletta.Biel@zut.edu.pl 
most popular ways of feeding dogs is to give them complete commercial feeds. Those include dry (below $14 \%$ of moisture), semi-moist (20-40\% of moisture) and wet (above $60 \%$ of moisture) products (Hołda et al. 2013). When a decision is made to feed the dog with dry food, the selection of feed should not be made based on its price but on its quality. Data provided on the label of the feed should facilitate evaluation of the product to dog owners. The label on the feed has two functions. First of all, it provides the consumer with comprehensive and reliable information required for making a conscious choice. Second of all, it allows for monitoring and controlling the manufacturer (Rozporządzenie Parlamentu Europejskiego i Rady (WE) nr 767/2009 z dnia 13 lipca 2009 r.). The label must include, among other information, declaration on the animal species for which it is intended, dosage, composition and declaration on moisture level (if it exceeds 14\%), as well as content of total protein, fat, crude fiber and crude ash (Rozporządzenie Ministra Rolnictwa i Rozwoju Wsi z dnia 29 maja 2007 r.; Hołda et al. 2013).

The aim of the study presented below was to evaluate nutritional value of commercial granulated adult dog feeds. Nutritional information provided by the manufacturers on the labels of analyzed feeds was also verified.

\section{MATERIAL AND METHOD}

The research material consisted of 9 commercial granulated maintenance feeds for adult dogs. Basic chemical composition of the feeds was identified in accordance with AOAC (2012). Crude protein $(\mathrm{N} \times 6.25)$ was identified by the Kjeldahl method, using a Büchi Scrubber B414 unit and a Büchi 324 distillation set. Crude fat was identified by Soxhleta method with diethyl ether used as solvent. Crude fiber was identified on the Ankom 220 Fiber Analizer. Crude ash - by burning in a muffle furnace at $580^{\circ} \mathrm{C}$ for 8 hours. Total carbohydrates (NFE/nitrogen free extract) were calculated according to the following formula:

$\mathrm{NFE}=$ dry matter - (crude protein + crude fat + crude fiber + crude ash)

Metabolisable energy (ME) of the feeds was calculated on the basis of identified chemical composition, according to equation provided by the National Research Council (2006), using modified Atwater factors:

ME $\left(\mathrm{kcal} \cdot 100 \mathrm{~g}^{-1}\right)=\%$ of crude protein $\times 3.5+\%$ of crude fat $\times 8.5+\%$ NFE $\times 3.5$

The results were compared with recommended share of basic nutrients for adult dogs determined by the FEDIAF (2013), as well as nutritional standards established by the National Research Council (2006).

All chemical identifications were performed in triplicate and were presented as mean values with standard deviation $( \pm S D)$. The results obtained were analyzed statistically using Statistica 12 software.

\section{RESULTS AND DISCUSSION}

Proper nutrition means providing the animal with all nutrients vital for its living and reproduction. Commercial feeds, both dry and wet, should constitute wholesome, balanced foods, the composition of which fully covers the animal's demand for basic nutrients, which gives them advantage over home diets. 
Table 1 presents basic chemical composition of selected commercial feeds. Significant differences were discovered in the share of tested components, depending on the feed. One of the most important nutrients in a dog diet is protein. Protein deficiency (including some amino acids) causes many metabolic disorders, anemia, immunodeficiency, weight loss, degenerative changes in organs, apathy, limitation of mobility (Grela 2016). It is suggested that in domestic dogs the protein content in diet affects the level of their aggressiveness. Feeding dogs with low protein feed can reduce their aggression of territorial nature (Kamieniak et al. 2015). Significantly most protein was found in feed no 5 (40.81 g $100 \mathrm{~g}^{-1} \mathrm{~d}$.m.), and least in feed no $2\left(22.11 \mathrm{~g} \cdot 100 \mathrm{~g}^{-1} \mathrm{~d} . \mathrm{m}\right.$.). The average content of this nutrient amounted to $21.72 \mathrm{~g}$, which is $17 \%$ above the minimum requirement. All tested feeds met minimum requirement for total protein, which is $18 \mathrm{~g} \cdot 100 \mathrm{~g}^{-1}$ of feed. Comparing protein content resulting from own analyses with information provided on the labels by the manufacturers showed that in 6 feeds out of 9 the manufacturers declared significantly lower protein share (on average $18 \%$ less) than actual share shown by analyses (Table 3 ). It is worth noticing that protein is also a source of flavor. Flavor increases with increased protein level (Brown 1989).

The amount and quality of fat consumed by dogs has great impact on development of obesity, diabetes, cardiovascular diseases and cancer. Reducing fat in the dog's diet and appropriate ratio of fatty acids can not only prevent but also cure diseases (Firląg et al. 2013). There is a tendency to reduce fat intake in human nutrition and dog owners tend to transfer their eating habits to pets. It is important to remember that reducing fats in pet diet should be balanced out by increasing intake of carbohydrates. Significantly most fat was found in feed no $5\left(17.38 \mathrm{~g} \cdot 100 \mathrm{~g}^{-1} \mathrm{~d} . \mathrm{m}\right.$.), and least in feed no $2\left(7.79 \mathrm{~g} \cdot 100 \mathrm{~g}^{-1} \mathrm{~d} . \mathrm{m}\right.$.). The average content of this nutrient amounted to $8.03 \mathrm{~g} \cdot 100 \mathrm{~g}^{-1} \mathrm{~d} . \mathrm{m}$., which is $32 \%$ more than minimum demand for adult dogs.

Table 1. Chemical composition of feeds [g $100 \mathrm{~g}^{-1}$ d.m.]

Tabela 1. Zawartość składników podstawowych w karmach $\left[\mathrm{g} \cdot 100 \mathrm{~g}^{-1}\right.$ s.m.]

\begin{tabular}{|c|c|c|c|c|c|c|}
\hline $\begin{array}{c}\text { Item } \\
\text { Wyszczególnienie }\end{array}$ & $\begin{array}{c}\text { Moisture } \\
\text { Wilgotność } \\
{\left[\mathrm{g} \cdot 100 \mathrm{~g}^{-1}\right]}\end{array}$ & $\begin{array}{l}\text { Crude protein } \\
\text { Białko ogólne }\end{array}$ & $\begin{array}{c}\text { Crude } \\
\text { fibre } \\
\text { Włókno } \\
\text { surowe }\end{array}$ & $\begin{array}{l}\text { Crude fat } \\
\text { Tłuszcz } \\
\text { surowy }\end{array}$ & $\begin{array}{l}\text { Crude ash } \\
\text { Popiół } \\
\text { surowy }\end{array}$ & NFE \\
\hline 1 & $\begin{array}{c}6.38^{\mathrm{a}} \pm \\
0.02\end{array}$ & $\begin{array}{c}37.77^{\mathrm{a}} \pm \\
0.11\end{array}$ & $\begin{array}{c}2.38^{c d} \pm \\
0.16\end{array}$ & $\begin{array}{c}16.05^{\mathrm{a}} \pm \\
0.09\end{array}$ & $\begin{array}{c}8.22^{\mathrm{a}} \pm \\
0.01\end{array}$ & $\begin{array}{c}35.58^{\mathrm{a}_{ \pm}} \\
0.17\end{array}$ \\
\hline 2 & $\begin{array}{c}7.39^{b} \pm \\
0.03\end{array}$ & $\begin{array}{c}22.11^{\mathrm{b}} \pm \\
0.06\end{array}$ & $\begin{array}{c}2.07^{\mathrm{d}} \pm \\
0.06\end{array}$ & $\begin{array}{c}7.79^{\mathrm{b}} \pm \\
0.14\end{array}$ & $\begin{array}{c}6.06^{\mathrm{b}} \pm \\
0.04\end{array}$ & $\begin{array}{c}61.97^{\mathrm{b}} \pm \\
0.09\end{array}$ \\
\hline 3 & $\begin{array}{c}6.12^{c_{ \pm}} \\
0.03\end{array}$ & $\begin{array}{c}25.72^{\mathrm{c}} \pm \\
0.04\end{array}$ & $\begin{array}{c}3.14^{\mathrm{bc}} \pm \\
0.17\end{array}$ & $\begin{array}{c}12.06^{c} \pm \\
0.10\end{array}$ & $\begin{array}{c}10.88^{c} \pm \\
0.09\end{array}$ & $\begin{array}{r}48.21^{\mathrm{c}} \pm \\
0.31\end{array}$ \\
\hline 4 & $\begin{array}{c}7.43^{\mathrm{bd}} \pm \\
0.06\end{array}$ & $\begin{array}{c}29.00^{\mathrm{dfi}_{ \pm}} \\
0.27\end{array}$ & $\begin{array}{c}2.43^{\mathrm{cd}} \pm \\
0.01\end{array}$ & $\begin{array}{c}8.79^{d} \pm \\
0.12\end{array}$ & $\begin{array}{c}8.90^{d} \pm \\
0.02\end{array}$ & $\begin{array}{c}50.89^{\mathrm{d}} \pm \\
0.14\end{array}$ \\
\hline 5 & $\begin{array}{c}5.83^{e_{ \pm}} \\
0.01\end{array}$ & $\begin{array}{c}40.81^{\mathrm{e}_{ \pm}} \\
0.23\end{array}$ & $\begin{array}{c}1.63^{\mathrm{d}} \pm \\
0.20\end{array}$ & $\begin{array}{c}17.38^{\mathrm{e}_{ \pm}} \\
0.06\end{array}$ & $\begin{array}{l}8.78^{d} \pm \\
0.03\end{array}$ & $\begin{array}{c}31.30^{\mathrm{e}_{ \pm}} \\
0.01\end{array}$ \\
\hline 6 & $\begin{array}{c}7.20^{f} \pm \\
0.04\end{array}$ & $\begin{array}{c}28.87^{\mathrm{fi}} \pm \\
0.02\end{array}$ & $\begin{array}{c}9.35^{\mathrm{a}} \pm \\
0.38\end{array}$ & $\begin{array}{c}9.00^{\mathrm{d}} \pm \\
0.16\end{array}$ & $\begin{array}{l}8.72^{\mathrm{d}} \pm \\
0.06\end{array}$ & $\begin{array}{c}44.06^{f_{ \pm}} \\
0.46\end{array}$ \\
\hline 7 & $\begin{array}{c}7.34^{\mathrm{bdg}} \pm \\
0.04\end{array}$ & $\begin{array}{c}24.08^{9 \pm} \\
0.05\end{array}$ & $\begin{array}{c}3.59^{\mathrm{b}} \pm \\
0.29\end{array}$ & $\begin{array}{l}9.11^{\mathrm{d}} \pm \\
0.19\end{array}$ & $\begin{array}{c}9.40^{\mathrm{e}} \pm \\
0.06\end{array}$ & $\begin{array}{c}53.819_{ \pm} \\
0.25\end{array}$ \\
\hline 8 & $\begin{array}{c}7.32^{\text {bhdfg }} \pm \\
0.01\end{array}$ & $\begin{array}{c}26.56^{h_{ \pm}} \\
0.32\end{array}$ & $\begin{array}{c}3.35^{\mathrm{b}} \pm \\
0.38\end{array}$ & $\begin{array}{c}9.83^{f} \pm \\
0.14\end{array}$ & $\begin{array}{c}7.57^{f} \pm \\
0.02\end{array}$ & $\begin{array}{c}52.70^{\mathrm{h}_{ \pm}} \\
0.18\end{array}$ \\
\hline 9 & $\begin{array}{c}6.13^{\mathrm{ie}_{ \pm}} \\
0.03\end{array}$ & $\begin{array}{c}28.83^{i} \pm \\
0.09\end{array}$ & $\begin{array}{c}2.26^{\mathrm{cd}} \pm \\
0.02\end{array}$ & $\begin{array}{c}8.63^{\mathrm{d}} \pm \\
0.07\end{array}$ & $\begin{array}{c}10.50^{9} \pm \\
0.01\end{array}$ & $\begin{array}{c}49.77^{i} \pm \\
0.15\end{array}$ \\
\hline Mean - Średnia & $\begin{array}{l}5.18 \pm \\
3.01\end{array}$ & $\begin{array}{c}21.72 \pm \\
13.32 \\
\end{array}$ & $\begin{array}{l}2.66 \pm \\
2.45\end{array}$ & $\begin{array}{l}8.03 \pm \\
5.29\end{array}$ & $\begin{array}{l}6.70 \pm \\
4.02\end{array}$ & $\begin{array}{l}36.83 \pm \\
22.35\end{array}$ \\
\hline $\begin{array}{l}\text { Minimal requirements } \\
\text { Zalecane minimum }\end{array}$ & & $18^{*}$ & & $5.50^{*}$ & & \\
\hline
\end{tabular}

NFE - nitrogen free extract - związki bezazotowe wyciągowe; * according to - według FEDIAF (2013); a, b, c, d, e, $f, g$ for - dla $p \leq 0.05$. 
Table 2. Comparison of data from own analyzer (I) and data provided by producers (II)

Tabela 2. Porównanie danych z analiz (I) z danymi podawanymi przez producenta (II)

\begin{tabular}{|c|c|c|c|c|c|c|}
\hline & \multirow[t]{2}{*}{$\begin{array}{c}\text { Item } \\
\text { Wyszczególnienie }\end{array}$} & $\begin{array}{l}\text { Crude protein } \\
\text { Białko ogólne }\end{array}$ & $\begin{array}{c}\text { Crude fibre } \\
\text { Włókno } \\
\text { surowe }\end{array}$ & $\begin{array}{l}\text { Crude fat } \\
\text { Tłuszcz } \\
\text { surowy }\end{array}$ & $\begin{array}{c}\text { Crude ash } \\
\text { Popiół } \\
\text { surowy }\end{array}$ & NFE \\
\hline & & \multicolumn{5}{|c|}{$\%$} \\
\hline \multirow{3}{*}{1} & I & $37.8^{a}$ & $2.4^{\mathrm{b}}$ & 16 & 8.2 & 35.6 \\
\hline & II & $33^{b}$ & $5^{a}$ & 17 & 8 & 37 \\
\hline & $\%$ & 114.5 & 47.5 & 94.4 & 102.7 & 103.9 \\
\hline \multirow{3}{*}{2} & I & $22.1^{b}$ & 2.1 & $7.8^{b}$ & 6.1 & $62^{a}$ \\
\hline & II & $25^{\mathrm{a}}$ & 2.5 & $12^{\mathrm{a}}$ & 6.5 & $53^{b}$ \\
\hline & $\%$ & 88.4 & 82.9 & 64.9 & 93.2 & 117 \\
\hline \multirow{3}{*}{3} & I & 25.7 & 3.1 & $12.1^{\mathrm{b}}$ & $10.9^{a}$ & 48.2 \\
\hline & II & 26 & 3 & $14^{a}$ & $8^{b}$ & 49 \\
\hline & $\%$ & 98.9 & 104.7 & 86.1 & 135.9 & 98.4 \\
\hline \multirow{3}{*}{4} & I & $29^{b}$ & $2.4^{a}$ & $8.8^{b}$ & $8.9^{a}$ & $50.9^{a}$ \\
\hline & II & $36^{a}$ & $1.5^{\mathrm{b}}$ & $18^{a}$ & $8^{b}$ & $36.5^{b}$ \\
\hline & $\%$ & 80.6 & 161.7 & 48.8 & 111.2 & 71.7 \\
\hline \multirow{3}{*}{5} & I & $40.8^{a}$ & 1.7 & 17.4 & 8.8 & 31.3 \\
\hline & II & $38^{\mathrm{b}}$ & 2.5 & 18 & 8 & 33.5 \\
\hline & $\%$ & 107.4 & 69 & 96.6 & 109.8 & 93.4 \\
\hline \multirow{3}{*}{6} & I & $28.9^{a}$ & $9.4^{a}$ & 9 & 8.7 & $44.1^{b}$ \\
\hline & II & $24^{b}$ & $6.7^{\mathrm{b}}$ & 9.8 & 7.7 & $51.8^{a}$ \\
\hline & $\%$ & 120.3 & 139.6 & 91.9 & 113.2 & 85.1 \\
\hline \multirow{3}{*}{7} & I & $24.1^{a}$ & 3.6 & 9.1 & 9.4 & 53.8 \\
\hline & II & $21^{\mathrm{b}}$ & 3.5 & 10 & 10 & 55.5 \\
\hline & $\%$ & 114.7 & 102.7 & 91.1 & 94 & 96.9 \\
\hline \multirow{3}{*}{8} & I & $26.6^{a}$ & 3.3 & $9.8^{a}$ & 7.6 & 52.7 \\
\hline & II & $21^{\mathrm{b}}$ & 3 & $8.5^{\mathrm{b}}$ & - & - \\
\hline & $\%$ & 126.5 & 111.5 & 115.6 & - & - \\
\hline \multirow{3}{*}{9} & I & $28.8^{a}$ & 2.3 & $8.6^{b}$ & $10.5^{a}$ & 49.8 \\
\hline & II & $23.5^{b}$ & 3.5 & $13^{a}$ & $6.5^{\mathrm{b}}$ & 53.5 \\
\hline & $\%$ & 122.7 & 64.5 & 66.4 & 161.6 & 93.1 \\
\hline
\end{tabular}

Explanation see Table 1 - Objaśnienia zob. tab. 1.

Table 3. Content of metabolisable energy in dog feeds [kcal ME $\cdot 100 \mathrm{~g}^{-1}$ ]

Tabela 3. Zawartość energii metabolicznej w karmach [kcal EM · $100 \mathrm{~g}^{-1}$ ]

\begin{tabular}{cc}
\hline Item & Metabolisable energy \\
Wyszczególnienie & Energia metaboliczna \\
\hline 1 & $437.86^{\mathrm{a}} \pm 0.14$ \\
2 & $406.40^{\mathrm{bch}} \pm 0.10$ \\
3 & $404.21^{\mathrm{d}} \pm 0.17$ \\
5 & $398.65^{\mathrm{e}} \pm 0.20$ \\
6 & $444.89^{\mathrm{e}} \pm 0.19$ \\
7 & $372.73^{\mathrm{f}} \pm 0.07$ \\
8 & $393.60^{\mathrm{gi}} \pm 0.09$ \\
9 & $405.49^{\mathrm{bch}} \pm 0.28$ \\
Mean - Średnia & $392.12^{\mathrm{i}} \pm 0.05$ \\
Minimal requirements - Zalecane minimum & 315.94 \\
\hline
\end{tabular}

${ }^{*}$ According NRC - według NRC.

Comparison of the results of own analyses and data provided in the feed labels showed that only in one case the manufacturer stated significantly lower (by 15\%) carbohydrate share than turned out as a result of analyses.

Mineral components constitute an important part of dog diet, since their intake affects not only the appearance of the pelage, but also the animal's health. Significantly most mineral components meant as crude ash were found in feed no $3\left(10.88 \mathrm{~g} \cdot 100 \mathrm{~g}^{-1} \mathrm{~d} . \mathrm{m}\right.$.), and least in feed no 2 (6.06 g $100 \mathrm{~g}^{-1}$ d.m.). 
The need for carbohydrates in dogs is associated with many factors, such as, for example, the dog's physiological condition. Most dogs do not need a high-carb diet. Nonetheless, commercial feeds usually contain a lot of carbs, due to the feed production technology and materials used.

One of the main sources of carbohydrates in commercial dog feed are cereals, to be exact starch contained in cereals. Cooked starch is well digested by dogs. Diet based on commercial feeds that are rich in starch should be diversified. Crude fiber is a part of digestive fiber and it is not digested in the digestive tract. However, some amount of crude fiber is necessary for proper intestinal and gastric motility (Mirkowski 2013). Various amounts of this component were found in the tested feeds, significantly most amount was traced in feed no 6 (9.35 g · $100 \mathrm{~g}^{-1}$ d.m.), and least in feed no 5 (1.63 g $100 \mathrm{~g}^{-1}$ d.m.). In two cases the manufacturer stated lower content of this component compared to the results of own analyses. Total calculated carbohydrate content (NFE) in tested dog feeds ranged from 31.30 to $53.81 \mathrm{~g} \cdot 100 \mathrm{~g}^{-1} \mathrm{~d} . \mathrm{m}$. The average content amounted to $36.83 \mathrm{~g} \cdot 100 \mathrm{~g}^{-1} \mathrm{~d} . \mathrm{m}$.

A properly balanced diet not only takes into account content of particular components, but also provides appropriate amount of energy, which ensures healthy development as well as maintenance of all body functions (Firląg et al. 2013). Table 2 presents amounts of metabolisable energy in the tested feeds. Significantly most metabolisable energy was found in feed no $1\left(437.86 \mathrm{kcal} \mathrm{ME} \cdot 100 \mathrm{~g}^{-1}\right)$, and least in feed no $6\left(372.73 \mathrm{kcal} \mathrm{ME} \cdot 100 \mathrm{~g}^{-1}\right)$. Four of the tested feeds did not meet minimum demand for metabolisable energy $(4,6,7 \mathrm{i} 9)$, on the average by $3 \%$.

\section{CONCLUSIONS}

To conclude, composition of granulated adult dog feeds is characterized by high variability, however it is worth noticing that all tested commercial feeds met basic requirements in terms of demand for both crude protein and crude fat. Calculated metabolisable energy of the majority of feeds was compliant with the recommended minimum. Some of the data provided by the manufacturers on labels differed from the results of the preformed own analyses.

\section{REFERENCES}

AOAC 2012. Official methods of analysis. 19th ed. Gaithersburg, USA, Association of Official Analytical Chemists.

Barteczko J. 2002. Żywienie psów w okresie rozrodu [Feeding dogs during breeding]. MW 11, 66, 29-32. [in Polish]

Brown R.G. 1989. Protein in dog food. Can. Vet. J. 30, 528-531.

Ceregrzyn M., Głowacka M. 2014. Zasady skutecznej konsultacji żywieniowej w praktyce lekarza weterynarii [Effective nutritional consultation in dog and cat veterinary practice]. MW 23(206), 696-704. [in Polish]

FEDIAF. 2013. Nutritional guidelines for cats and dogs. Bruxelles, Europ. Pet Food Ind. Feder.

Firląg M., Gaca K., Bałasińska B. 2013. Zastosowanie wielonienasyconych kwasów tłuszczowych n-3 w leczeniu psów i kotów [Polyunsaturated fatty acids n-3 in dogs and cats therapy]. Życie Weter. 88(7), 565-567. [in Polish] 
Grela E.R. 2016. Behawioralne następstwa nieprawidłowego żywienia zwierząt [Behavioral consequences of improper animal feeding]. Życie Weter. 19(2), 93-96. [in Polish]

Hołda K., Głogowski R., Berwid-Wójtowicz S. 2013. Wymagania dotyczące etykietowania karm pełnoporcjowych dla psów i kotów [Requirements concerning labeling of full-ration feeds for dogs and cats]. Prz. Hod. 5, 29-30. [in Polish]

Kamieniak J., Mazurkiewicz T., Tietze M. 2015. Modyfikujący wpływ człowieka na zachowanie się psa domowego [Modifying human impact on the behawior of domestic dogs]. Życie Weter. 90(6), 368-371. [in Polish]

Mielczarek M., Szydłowski K. 2017. The heavy metal content in commercial dog foods. Folia Pomer. Univ. Technol. Stetin., Agric., Aliment., Pisc., Zootech. 332(41)1, 29-36.

Mirkowski M. 2013. Czy węglowodany są niezbędne w żywieniu psów i kotów? [Are dietary carbohydrates essential for dog and cat nutrition?]. Życie Weter. 88(10), 870-872. [in Polish]

Mirowski A. 2014. Zagrożenia związane z żywieniem psów i kotów surowymi karmami pochodzenia zwierzęcego [Potential hazards associated with feeding of raw meat-based diets to dogs and cats]. MW 23(206), 705-709. [in Polish]

NRC. 2006. National Research Council. Nutrient requirements of dogs and cats. Washington, D.C.

Rozporządzenie Ministra Rolnictwa i Rozwoju Wsi z dnia 29 maja 2007 r. w sprawie oznakowania pasz. DzU z 2007 r., nr 102, poz. 703. [in Polish]

Rozporządzenie Parlamentu Europejskiego i Rady (WE) nr 767/2009 z dnia 13 lipca 2009 r. w sprawie wprowadzania na rynek $i$ stosowania pasz, zmieniające rozporządzenie (WE) Parlamentu Europejskiego i Rady i uchylające dyrektywę Rady 79/373/EWG, dyrektywę Komisji 80/511/EWG, dyrektywy Rady 82/471/EWG, 83/228/EWG, 93/74/EWG, 93/113/WE i 96//25/WE oraz decyzję Komisji 2004/217/WE. DzU z 1.09.2009 r., L 229. [in Polish]

Witkowska 0. 2015. Żywienie a behawior psów i kotów [Nutrition and behavior of dogs and cats]. Życie Weter. 90(9), 573-576. [in Polish]

\begin{abstract}
One of the most popular methods of feeding dogs is giving them complete commercial feeds. When a decision is made to feed the dog with a dry food, selection of feed should not be made based on its price but in the first place on its quality. The research material consisted of 9 commercial maintenance feeds for adult dogs. The feeds tested were in granular form. Basic chemical composition in dry matter was determined for each feed (total protein, crude fiber, crude fat, crude ash and nitrogen-free extracts). Obtained results were compared with data provided by the manufacturers on labels of testes feeds. Metabolisable energy was calculated for each feed, based on the calculated chemical composition. All tested feeds satisfied minimal demand for total protein and crude fat. Three of them did not, however, meet minimum standard for adult dog feeds with respect to the level of metabolisable energy. Comparison of data on nutritional value provided by the manufacturers with results of own analyses showed that in several cases the manufacturers over- or underestimated content of particular nutrients. In 6 out of 9 feeds the manufacturers declared significantly higher content of protein. In one case the manufacturer declared significantly lower fat content that the one resulting from performed chemical analyses.
\end{abstract}

